\title{
Re-engineering of Business Processes in Sick Business Sectors to set up Sustainable Growth
}

\author{
Debayan Nandi \\ Head, Department of Business Administration \\ Siliguri Institute of Technology, Siliguri \\ Sohini Guha \\ Asst Prof, Department of Business Administration \\ Siliguri Institute of Technology, Siliguri
}

\begin{abstract}
This article is conceptualized with different spheres of corporate restructuring and business process reengineering (BPR). Attention is paid to find out the relationship between corporate restructuring and business process reengineering as well as to identify their main challenges to apply in sick business sectors of different Indian organizations as turn-key solutions. The term corporate revitalization is justified and the idea of business renaissance is portrayed by optimizing the resource allocation and minimizing the threats.
\end{abstract}

Key words: Business process reengineering (BPR), turn-key solutions, corporate revitalization

\section{INTRODUCTION}

Most predominantly, Business Process Reengineering (BPR) began as a technique to help organizations essentially to rethink how they can do their application in order to noticeably perk up customer service, reduce operational costs, but become or remain as world-class competitors. Hammer \& Champy (1993) introduced Business Process Reengineering as a widely used method for managing changes, most importantly for impending benefits such as augmented productivity over time of the process by reducing costs, better quality and to ensure higher customer delight. A key spur for BPR has been the long-lasting improvement and use of refined information systems and networks. Corporate leaders are pertinent in using this philosophy to prop up pioneering business activities. Market leaders are attracted towards BPR which are in crying need to reduce overall costs however to render continuous advance service factors to meet the changing needs of the customers. This direction is premeditated to facilitate auditors to appraise business process reengineering projects in an ideal and applicable setting, settling on the accuracy of these actions.

The key estimation issues in this direct pact with elements measured by experts to be the springboard to boom business process reengineering. These key success factors enfold nine interrelated activities, namely

i. Identifying customer needs

ii. Identifying performance problems of the product/service or key persons involved

iii. Reassessing tactical goals

iv. Defining reengineering opportunities

v. Managing reengineering projects

vi. Controlling risks

vii. Maximizing benefits of the present resources

viii. Managing organizational changes and

ix. Successfully implementing new processes.

All these issues make available a general scaffold for assessing a reengineering project, from initial strategic planning and goal-setting to post-implementation assessments.BPR is now well thought-out to be very flourishing though there some major stories of failures of BPR too in some industries. One of the major constraint in thriving 
accomplishment of BPR projects highlight lack of reverence for man power issues. Aghassi (1994), commented that, BPR is habitually perceived as a contrivance for reorganizing the organizational processes, where the employees are considered as a burden. This perception may actually be misleading that, manpower rightsizing is a concept often pronounced with BPR, which is measured as a lessening in the number of personnel and organizations to accomplish cost reductions through process redesign advantage of fast trying to see what happens. Davenport (1995) explained, BPR as the movement that ignore people management factor, even though he had also mentioned that "reengineering didn't start as a code word for mindless bloodshed".

BPR swathe all the projections and areas through which organization can manipulate cost of production and built efficient organizational principles; when the amalgamation of BPR and human resources starts giving the effective outcomes to the organization based on their own efforts; the competitive advantage of the organization aspire to grow for BPR and can redirect their HR practices towards implementation of the redefined practices more effectively and also to increase the productivity with much reduced costs. Five major wings that strengthen the operational issues of BPR are as follows:

\section{(i) Managerial Competence}

Managerial competence depends on top management's obligation and it speculates the area of top management's plan of inclination for customer satisfaction all through process reengineering employee's support to the bizarre performance understanding (Hammer \& Stanton, Holland \& Kumar, 1995). The role of top management in BPR is to give assurance to step forward towards competitive advantage that adds to organizational development too (Guimaraes \& Bond,1996). Top management must make available a comprehensible vision to form possible BPR team members toward the preferred results (Sung \& Gibson, 1998). It makes certain that the BPR parameters should be augmented in a constructive move (Bashein, 1994). Managerial commitment and guidance are the key features of an unbeaten BPR project (Hammer, Stanton, Zairi and Karuppan \& Cooper and Markus, 1995) Leadership has to be bold, effective and creative in understanding and for providing an understandable idea of the future.

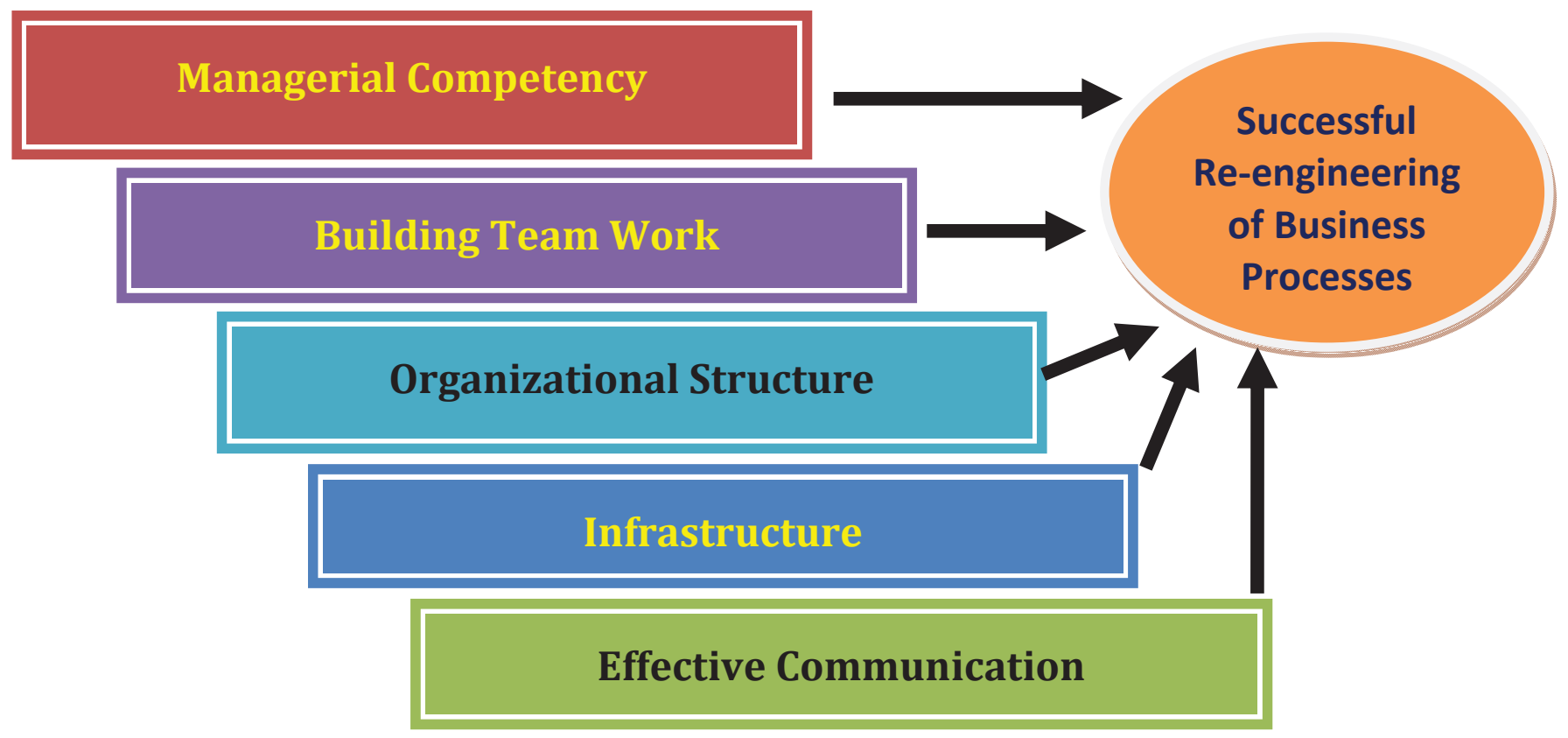

Figure 1 : Five major factors that strengthen the operational issues of BPR 


\section{(ii) Team Work Building}

Grint ,1994 in his literature on BPR described, "teams are measured an important ingredient to accomplish all the profit of a process orientated organization". Researchers often bring into being less productive measures by individual with new technology in comparison to teamwork with lesser or sometime no new technology. Team work is improved because it is the mishmash of the assortment of functions in one unit. Davenport (1993) gave importance in his research that, backing by using teams is connected to the augmentation of the merit of the work life. It is defined as the degree at which organizational standard and principles develop into satisfactory to the employees. Valuable organizational culture shows signs of professionalism towards its employees that work as team and achieve preferred goals and objectives.

(iii) Organizational structure

In BPR projects of sick units new processes may be implemented that define works and accountabilities on the cross to present organizational functions (Davenport \& Short, 1990), when there is an reasonable prerequisite to launch a new organizational structure that set up to focus how BPR teams work, how employees are integrated, and how the new jobs and responsibilities are going away to be formal. Accomplishment of the adequate human resources is exceptionally imperative for prosecutions of the BPR project (Zairi and Sinclair, 1995).

(iv) Infrastructure

Information Technology infrastructure of the organization configures organizational expenditures acquired on overall infrastructures and personnel training. Information Technology (IT) is the automation of succession and invention by computers, telecommunications, and software's, used to cover the different levels of the business through electronic techniques (Irechukwu,2000). Effective and adequate infrastructure of IT linked with BPR strategy, results adequate dimension of organizational efficiency, market growth and functional competency. This type of expansion aims at rapid and all-embracing in organizational performance by varying in core process (Laudon and Laudon, 2001)

\section{(v) Effective communication}

In BPR project implementation stage effective communication in organization avoids apparent grapevines and sort out unwanted noises. Every developmental change in organizational policies or processes are directed to accomplish goals. Communication must be clearly expressed, unfastened and explicable (Davenport and Janson, 2000). Reckoning of the effective communication is very significant to implement successful BPR-linked change efforts (Davenport, 1993). Communication requires constant modification in BPR process in view of the fact that at all stages and for all consultation with whom they don't get mixed up instantly in the value addition functioning (Dixon, 1994).

\section{METHODOLOGY ADOPTED}

Conceptual Model adopted to frame this paper. Research was based on the aim to study the validity of the BPR projects and human resource management under the study of the literature on BPR. The purpose of the research was to study the validity of the interpretation on BPR projects and it's best application in sick business units through the guidance available in the BPR literatures. Desk research data was collected through various literatures and survey of various organizations functioning, where BPR projects got recently implemented. Conducted mainly unstructured interview and relied upon advisor opinion since BPR is wide-reaching valid procedure of business reorganization focusing point on business processes, provided that huge improvements in a specific identified period. The implementation of organizational change on the foundation of a methodology for effective communication, team working organizational structure maintain by information technology were kept under count to conceptualize the best possible solutions. A theoretical scaffold that makes reasonable intellect of relationship among variables those are important for the thriving implementation of BPR. 


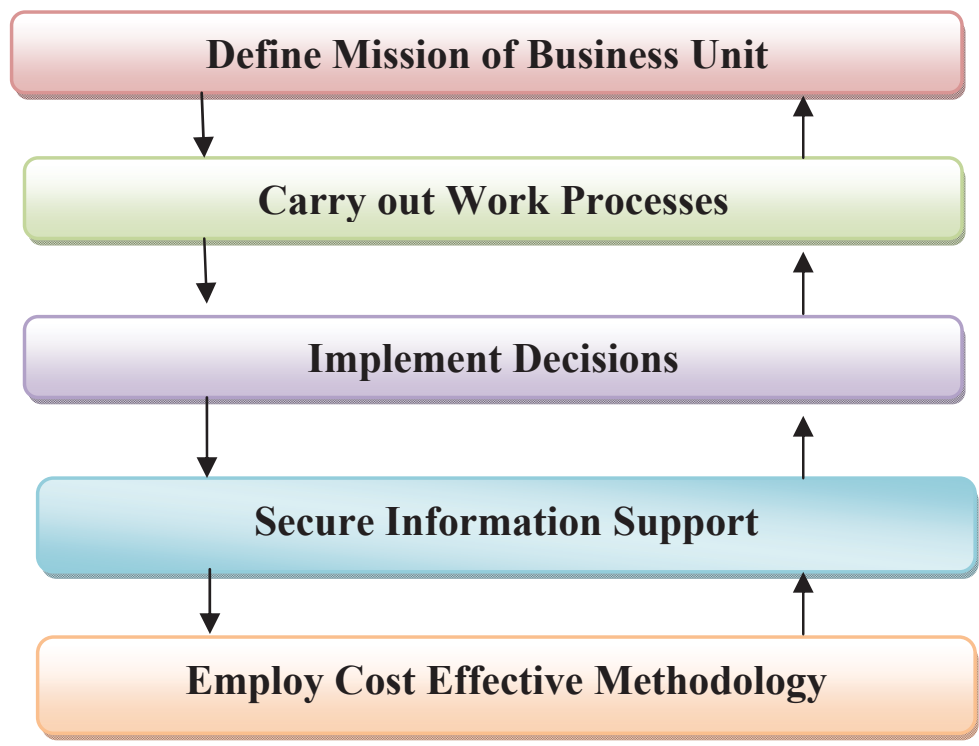

Figure 2: Step by Step Accomplishment of BPR in the organizations

Two major components of a company restructuring include financial restructuring and company management system restructuring. Financial restructuring of a changing company targets investments into a company progress, by and large sourcing of outsourced capital. Whereas a company management system restructuring is a spruce up of processes carried on within a firm. A successful restructuring progression involves the apprehension of restructuring measures in all spheres of business actions. It means some measures in the sphere of finance, properties, production, business, organization, information and personnel.

\section{THREE PRONGED APPLICATIONS OF BUSINESS PROCESS REENGINEERING IN ANY SICK BUSINESS UNIT}

(i) Transformation focuses fundamental reformulation of a company mission, strategy and innovative aspects; it is often consistent with peripheral conditions and links with the overall company structure - in terms of financial assets, supply of raw materials, production process, sales and distributions.

(ii) Integration includes reviewing, reformulations of company's new visions and ideologies, shows the way to new company architecture. It also accentuates amalgamation effects in organizational structures, work pattern, positions and power distributions of the officials, operational hindrances, prudent company processes and collective arrangements.

(iii) Rationalization or redesign highlights process or company structure simplification that inclines to the process of a quality improvement through quality circle when nothing gets completely tainted and maintains "status quo".

\section{CONCLUSION}

A financially or market ably sick company's BPR is a holistic revolutionary process that depends on shaping right restructuring measures. This denotes insightful strategic changes that can noticeably blow existing organizational principles and cultures rather than creating superficial or slow incremental changes. A triumphant BPR calls for reformation of all square company activities in the functional areas of finance, workforce, assembly, sales, purchases and information. So, it can be concluded by saying that corporate restructuring is closely coupled with business process reengineering. 


\section{REFERENCES}

[1] Bartol, K. M., Martin, D. C. Management. 3rd ed. Boston: McGraw-Hill, 1998. 779 p.

[2] ISBN 0-07-115206-7

[3] Gaughan, P. A. Mergers, Acquisitions and Corporate Restructuring. 3rd ed. New York: John Wiley \& Sons, 2002. 612 p. ISBN 0-47112196-7

[4] Hammer, M., Champy, J. Reengineering - radikální proměna firmy. 3rd ed. Praha: Management Press, 2000. 212 p. ISBN 80-7261-028-7

[5] Harrison, J. S., John, C. H. Strategic Management of Organizations and Stakeholders. 2nd ed. Cincinnati: South-Western College Publishing, 1998. 432 p. ISBN 0-538-87839-8

[6] Ivanov, A. Ne každá změna v podniku je reinženýring. Moderní řízení, 2003, Vol. XXXVIII, No. 3, p. 29 - 30. ISSN 0026-8720

[7] Jirásek, J. Ř́zení revitalizace malého a středního podniku. In: Konference „GEMAN 2001 - General Management“; Mariánské Lázně 20. 21. 9. 2001, 1. vyd., 2001, s. 153 - 170. ISBN 80-902692-8-1

[8] Johnson, G.; Scholes, K. Exploring Corporate Strategy. 5th ed. Harlow: Prentice Hall, 1999. 972 p. ISBN 0-13-080740-0

[9] Kratochvílová, H. Restrukturalizace, oživení a záchrana podniku. 1st ed. Praha: Prospektrum, 2001. 240 p. ISBN 80-7175-087-5

[10] Myšková, R. Interní podnikové procesy při realizaci podnikové strategie. In: International Conference „Ekonomika firiem 2001“, PHF Košice, Svit 12. - 14. 9. 2001, 1st ed., 2001, p. 527-531. ISBN 80-225-1446-2

[11] Pamphilis, D. Mergers, Acquisitions, and other Restructuring Activities. 1st ed. San Diego: Academic Press, 2001. 643 p. ISBN 0-12210735-7

[12] Robbins, S. P., Coulter, M. Management. 6th ed. London: Prentice Hall, 1996. 645 p. ISBN 0-13-961921-6

[13] Synek, M. Restrukturalizace a revitalizace českých podniků. In: International Conference „Ekonomika firiem 2001“, PHF Košice, Svit 12. 14. 9. 2001, 1st ed., 2001, p. 672-677. ISBN 80-225-1446-2

[14] Tichy, N. M. Managing Strategic Change - Technical, Political and Cultural Dynamics. 1st ed. New York: Interscience Publication, 1983. 434 p. ISBN 0-471-86559

[15] Tománek, J. Reengineering a management změn. 1st ed. Praha: Computer Press, 2001. 515 p. ISBN 80-7226-428-1

[16] Truneček, J. Restrukturalizace řízení malých a středních podnikủ. In: International Conference „Ekonomika firiem 2000“, PHF Košice, Snina 7. - 9. 9. 2000, 1st ed., 2000, p. 624 - 632. ISBN 80-225-1308-3 